\title{
Kasus-kasus Buruk Penggunaan Metode Titik Interior pada Optimisasi Linear
}

\author{
Bib Paruhum Sialalahi \\ Departemen Matematika, Fakultas MIPA, Institut Pertanian Bogor \\ Jl. Meranti, Kampus IPB Darmaga, Bogor, 16680 \\ Email: bibparuhum1@yahoo.com
}

\begin{abstract}
ABSTRAK
Metode titik interior adalah suatu metode dengan waktu polinomial dalam menyelesaikan masalah optimisasi linear. Metode titik interior sering menggunakan central path sebagai panduan menuju solusi optimalnya. Pada paper ini diberikan suatu teorema yang menyatakan bahwasanya kendala redundan dapat mengubah pusat analitik central path yang sekaligus mengubah central path. Dengan bantuan teorema ini ditampilkan suatu kasus dimana metode titik interior berunjuk kerja buruk dengan adanya kendala redundan. Kemudian disajikan suatu masalah optimisasi linear yang memiliki central path dengan pola zigzag. Pola zigzag pada central path juga mengakibatkan metode titik interior bekerja lebih lama dalam menuju solusi optimal.
\end{abstract}

Kata kunci: metode titik interior, central path, pola zigzag, kendala redundan, kasus buruk, optimisasi linear.

\section{ABSTRACT}

Interior point method is a method with polynomial time for solving linear optimization problems. Interior point methods often use the central path as a guidance to the optimal solution. In this paper, we present a theorem which states that the redundant constraints can change the analytic center of the central path and therefore change the central path. With the help of this theorem, we present a case where an interior point method has bad performance. Then we also present a linear optimization problem which has central path with a zigzag pattern. Zigzag pattern of the central path led an interior point method work longer than usual towards the optimal solution.

Keywords: interior point method, central path, zigzag pattern, redundant constraints, bad cases, linear optimization.

\section{Pendahuluan}

Permasalahan optimisasi linear (OL) adalah suatu permalahan dimana seseorang ingin meminimumkan atau memaksimumkan suatu fungsi tujuan yang berbentuk linear dengan kendala-kendala yang dinyatakan dalam persamaan linear dan/atau pertaksamaan linear. Penelitian-penelitian optimisasi linear telah membentuk catatan yang panjang, dimulai pada tahun 1947 sewaktu Dantzig memaparkan metode simpleks untuk menyelesaikan masalah OL [1]. Kelemahan dari metode simpleks adalah jumlah iterasi yang diperlukan untuk menyelesaikan masalah OL dapat tumbuh secara eksponensial. Hal ini ditunjukkan pertama sekali oleh Klee dan Minty [8]. Klee dan Minty memberikan contoh dimana metode simpleks memerlukan $2^{n}-1$ iterasi untuk menyelesaikan masalah OL dengan $2 n$ pertidaksamaan. Berikut adalah masalah Klee-Minty dimensi $n$ :

$$
\begin{aligned}
& \min _{n} \\
& \text { kendala } \rho y_{k-1} \leq y_{k} \leq 1-\rho y_{k-1}, \quad k=1, \ldots, n,
\end{aligned}
$$

dimana $\rho$ adalah bilangan positif lebih kecil dari setengah dan $y_{0}=0$. Dapat diverifikasi bahwa jumlah vertex di dalam domain masalah Klee-Minty ada sebanyak $2 n$. Klee-Minty menunjukkan bahwasanya dengan aturan pivot Dantzig, metode simpleks akan mengunjungi semua verteks, yang berarti waktu komputasi yang diperlukan adalah eksponensial $\left(2^{n}-1\right)$. Sejak itu hampir untuk semua aturan pivot metode simpleks dapat diberikan contoh yang memerlukan waktu eksponensial.

Pada tahun 1979, Kachiyan memaparkan suatu metode baru untuk menyelesaikan masalah OL dengan waktu polinomial[7]. Metode ini dikenal dengan nama metode elipsoid. Tetapi dalam aplikasinya metode elipsoid lebih buruk dari metode simpleks.

Pada tahun 1984, Karmarkar mengusulkan metode dengan waktu polinomial yang dikenal dengan nama metode projektif Karmarkar untuk menyelesaikan masalah OL [6]. Metode ini adalah awal 
dari berkembangnya metode titik interior. Metode ini juga efisien dalam aplikasinya. Cara yang sering digunakan metode titik interior dalam pendekatan menuju solusi optimal adalah dengan menggunakan central path, sebagai panduan. Suatu contoh metode yang menggunakan central path dipresentasikan oleh Roos dan Vial [10]. Untuk suatu problem dengan $n$ pertidaksamaan dan $L$ bit input data, metode mereka memerlukan $O \sqrt{n} L$ iterasi. Iterasi tersebut merupakan batas atas terbaik yang diketahui untuk metode-metode titik interior.Kemudian Roos, Terlaky dan Vial mendapatkan batas atas yang sama dengan menggunakanalgoritme yang disebut dengan primaldual langkah full-Newton [11]. Batas atas iterasi mereka dinyatakan dalam:

$$
\left\lceil\sqrt{2 n} \ln \frac{n \mu^{0}}{\varepsilon}\right\rceil
$$

dimana $\mu^{0}>0$ menotasikan nilai awal barrier parameter, dan $\varepsilon$ adalah akurasi mutlak dari fungsi tujuan. Buku tersebut menerangkan bahwa bila seseorang memilih nilai $\varepsilon$ yang cukup kecil maka batas atas akan ekivalen dengan $\sqrt{n} L$.

Central path adalah kurva analitik yang bergerak pada interior dari suatu domain menuju solusi optimal. Idealnya central path adalah suatu kurva mulus menuju solusi optimal. Dalam hal ini metode titik interior dengan central path sangat efisien. Dalam prakteknya kurva mungkin memiliki beberapa belokan-belokan tajam, yang dapat mengakibatkan kinerja metode titik interior menjadi buruk.

Deza, Nematollahi, Peyghami dan Terlaky [2] menunjukkan bahwa dengan menambahkan suatu kendala-kendala redundan terhadap masalah Klee-Minty, dapat memaksa central path memiliki belokan-belokan yang tajam. Beberapa jenis kendala redundan kemudian dianalisis, seperti dapat dilihat pada [3, 4, 9], yang memberikan contoh kasus buruk metode titik interior. Gilbert, Gonzaga dan Karas memberikan contoh buruk central path pada masalah optimisasi konveks [5].

Pada paper ini diberikan contoh kasus dimana pengunaan metode titik interior untuk masalah OL dapat memiliki unjuk kerja yang buruk.

\section{Metode Penelitian}

Penelitian ini dilakukan dengan menggunakan analisis matematika dan dengan bantuan perangkat lunak MATLAB.

\section{Hasil dan Pembahasan}

Bentuk standar dari masalah OL adalah sebagai berikut:

$$
\min \left\{c^{T} x \quad: \quad A x=b, x \geq 0\right\},
$$

dimana $c, x \in R^{n}, b \in R^{m} \operatorname{dan} A \in R^{m x n}$.

Masalah (P) sering disebut dengan masalah primal. Setiap masalah OL berpadanan dengan masalah OL lainnya yang disebut dengan masalah dual, yang mengandung data $(A, b, c)$ yang sama namun dinyatakan dengan cara yang berbeda. Dual dari (P) adalah:

$$
\max \left\{b^{T} y: A^{T} y+s=c, \mathrm{~s} \geq 0\right\},
$$

dimana $s \in R^{n}$ dany $\in R^{m}$. Mencari solusi optimal (P) dan (D) dengan menggunakan metode titik interior dapat dilakukan dengan menyelesaikan sistem persamaan berikut:

$$
\begin{aligned}
& A x=b, \quad x \geq 0, \\
& A^{T} y+s=c, \quad s \geq 0, \\
& x s=\mu e .
\end{aligned}
$$


dimana $\mu$ adalah sembarang bilangan positif dan $e$ adalah vektor satu.

Jika sistem tersebut memiliki solusi untuk beberapa $\mu>0$, maka dikatakan (P) dan (D) memenuhi kondisi interior. Ketika $\mu$ dievaluasi pada $(0, \infty)$ maka $x(\mu)$ akan memiliki suatu kurva pada interior daerah fisibel $(\mathrm{P})$, kurva inilah yang disebut dengan central path $(\mathrm{P})$. Demikian pula himpunan $\{(y(\mu), s(\mu)): \mu \in(0, \infty)\}$ disebut dengan central path (D).

Jika $\mu \rightarrow 0$ maka $x(\mu),(y(\mu), s(\mu))$ konvergen ke himpunan solusi optimal (P) dan (D). Pada sisi lain, jika $\mu \rightarrow \infty$ maka $x(\mu),(y(\mu), s(\mu))$ masing-masing konvergen ke pusat analitik dari (P) dan (D).

\subsection{Masalah Optimisasi Linear dengan Kendala Redundan}

Pada bagian ini diberikan suatu teorema dimana central path dari suatu masalah OL bergantung pada representasi dari masalah OL tersebut. Penambahan kendala-kendala redundan dapat mengubah central path masalah awal. Berikut didefinisikan pengertian kendala redundan.

Definisi 1. Kendala redundan adalah suatu kendala dimana penghapusan kendala tersebut dari suatu masalah OL tidak mengubah daerah fisibel dari masalah OL tersebut.

Selanjutnya diperlihatkan bahwa central path dari suatu masalah OL berubah ketika ditambahkan kendala redundan ke masalah awal OL. Tentu saja nilai optimal fungsi tujuan masalah OL dan masalah redundannya adalah sama. Ini berimplikasi bahwa jika masalah OL hanya memiliki satu solusi optimal maka untuk $\mu \rightarrow 0$, central path dari kedua masalah konvergen ke solusi yang sama. Sebaliknya jika $\mu \rightarrow \infty$ maka central path konvergen ke pusat analitik masalah. Teorema berikut memperlihatkan bagaimana pusat analitik berubah ketika kendala redundan ditambahkan ke masalah (D). Dalam pembuktian diperlukan lemma berikut :

Lemma 2. Jika kondisi interior terpenuhi, maka pusat analitik (D) adalah solusi unik dari sistem:

$$
\begin{aligned}
& A x=0, \quad x \geq 0, \\
& A^{T} y+s=c, \quad s \geq 0, \\
& x s=e .
\end{aligned}
$$

Bukti.

Dapat diperoleh bahwa jika kondisi interior terpenuhi maka sistem berikut terpenuhi.

$$
\begin{aligned}
& A\left(\mu^{-1} x\right)=\mu^{-1} b, \quad x \geq 0, \\
& A^{T} y+s=c, \quad s \geq 0, \\
& \mu^{-1} x s=e .
\end{aligned}
$$

Lemma didapatkan dengan mendefinisikan kembali $x$ sebagai $x:=\mu^{-1} x$, dan dengan mengambil $\mu$ menuju tak terhingga. $\square$

Berikut ini disajikan pembahasan dari teorema utama dari makalah ini.

Theorem 3. Misal $a^{T} y \leq d, a \in R^{m}, d \in R$, sebuah kendala redundan (D). Dengan menambahkan kendala ini ke (D) sebanyak $h$ kali, dan dengan mengambil $h$ menuju takterhingga, maka pusat analitik dari masalah baru OL, dinotasikan dengan (DR), konvergen ke sebuah solusi optimal dari

$$
\min \left\{a^{T} y: A^{T} y \leq c\right\},
$$

Bukti.

Ketika menambah kendala redundan $a^{T} y \leq d, h$ kali ke (D), diperoleh masalah redundan berikut:

$$
\max \left\{b^{T} y: A^{T} y \leq c, a^{T} y \leq d(h \text { kali) }\},\right.
$$

Masalah dual (DR) adalah 


$$
\min \left\{c^{T} x+h \bar{x} d: A x+h \bar{x} a=b, x \geq 0, h \bar{x} \geq 0\right\},
$$

dimana $\bar{x} \in R$. Menurut Lemma 2, pusat analitik (DR) secara unik ditentukan oleh sistem berikut:

$$
\begin{aligned}
& A x+h \bar{x} a=0, x \geq 0, \quad \bar{x} \geq 0, \\
& A^{T} y+s=c, \quad s \geq 0, \\
& a^{T} y+\bar{s}=d, \quad \bar{s} \geq 0, \\
& x s=e, \\
& \bar{x} \bar{s}=1,
\end{aligned}
$$

Membagi persamaan-persamaan (2) dan (5) dengan $h \bar{x}$ dan kemudian mendefinisikankembali $x$ sehingga $x:=x / h \bar{x}$, didapat sistem berikut:

$$
\begin{aligned}
& A x=-a, x \geq 0,(7) \\
& A^{T} y+s=c, \quad s \geq 0, \\
& a^{T} y+\bar{s}=d, \quad \bar{s} \geq 0, \\
& x s=\frac{e}{h \bar{x}}, \\
& \bar{x} \bar{s}=1 .
\end{aligned}
$$

Dengan mengambil $h \rightarrow \infty$, diperoleh dari (10) bahwa

$$
x s=0 .
$$

Karena (7), (8) dan (12) adalah kondisi-kondisi optimal untuk (1), lemma diperoleh.

\subsection{Masalah Klee-Minty dengan Kendala Redundan}

Berikut ini akan disajikan central path dari masalah Klee dan Minty dengan penambahan kendala redundan. Masalah awal Klee-Minty yang digunakan adalah masalah 2-dimensi dengan $\rho=$ 1/3, seperti sbb:

$$
\begin{aligned}
& \min y_{2} \\
& \text { kendala } 0 \leq y_{1} \leq 1, \\
& \frac{1}{3} y_{1} \leq y_{2} \leq 1-\frac{1}{3} y_{1} .
\end{aligned}
$$

Kendala redundan yang digunakan adalah kendala yang disajikan pada kolom pertama Tabel 1. Kolom kedua menyatakan gambar yang memperlihatkan efek pada central path ketika kendala yang bertautan ditambahkan $h$ kali, untuk beberapa nilai $h$. Dari Gambar 1 dan 2 dapat dilihat bahwa jika $h$ bertambah besar maka pusat analitik bergerak ke suatu titik dari kotak Klee-Minty dimana slack kendala redundan dimaksimumkan, yang sejalan dengan Teorema 3.

Table 1. Kendala redundan masalah (13) dan gambar tautan.

\begin{tabular}{|c|c|}
\hline Kendala redundan & Gambar \\
\hline$y_{1} \geq 0$ & $1(\mathrm{a})$ \\
\hline$y_{1} \leq 1$ & $1(\mathrm{~b})$ \\
\hline$y_{2} \geq 0$ & $1(\mathrm{c})$ \\
\hline$y_{2} \leq 1$ & $1(\mathrm{~d})$ \\
\hline$y_{2}+\frac{1}{3} y_{1} \geq 0$ & $2(\mathrm{a})$ \\
\hline$y_{2}+\frac{1}{3} y_{1} \leq 1.1$ & $2(\mathrm{~b})$ \\
\hline$y_{2}-\frac{1}{3} y_{1} \geq-0.1$ & $2(\mathrm{c})$ \\
\hline$y_{2}-\frac{1}{3} y_{1} \leq 1$ & $2(\mathrm{~d})$ \\
\hline
\end{tabular}




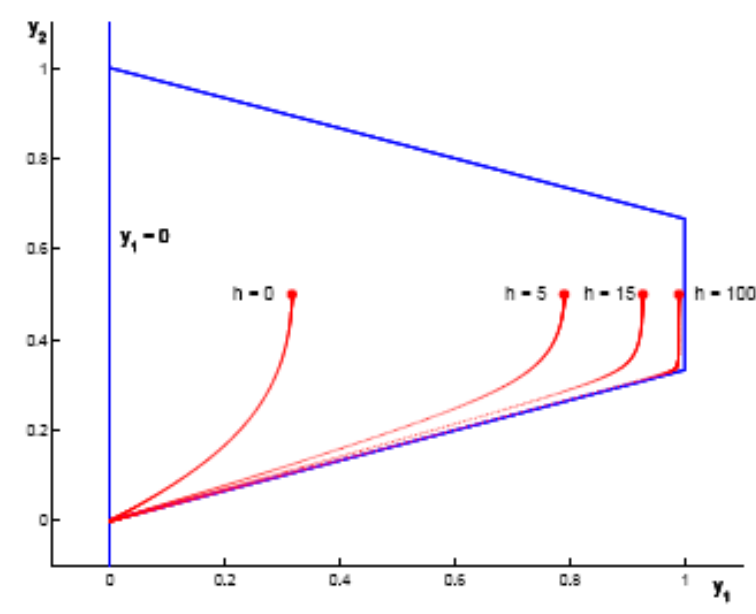

(a) $y_{1} \geq 0$

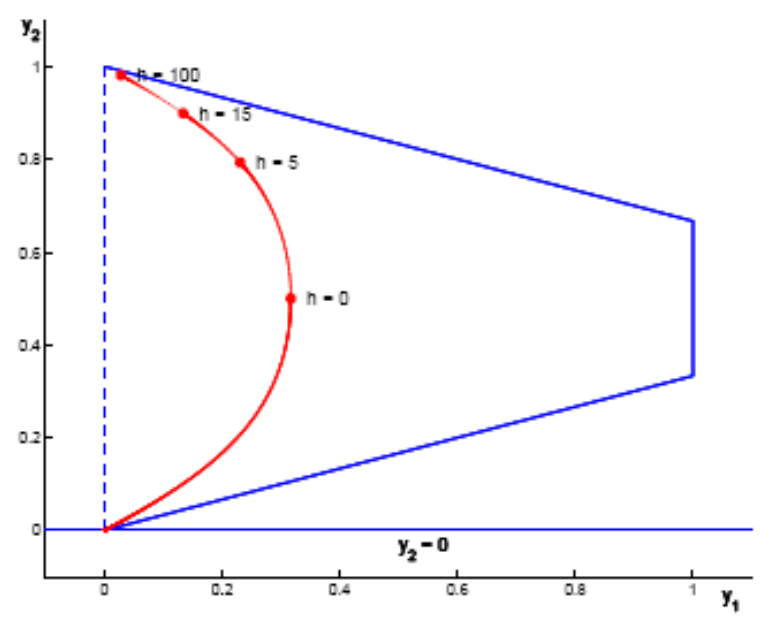

(c) $y_{2} \geq 0$

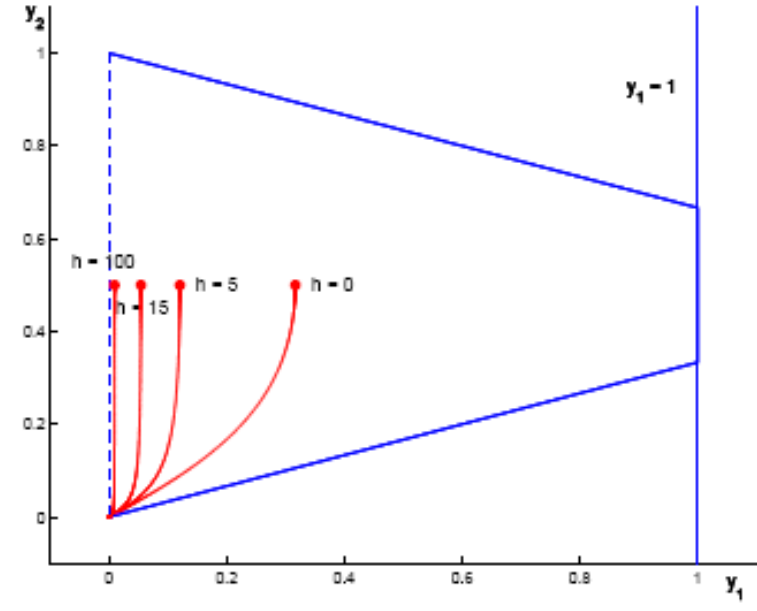

(b) $y_{1} \leq 1$

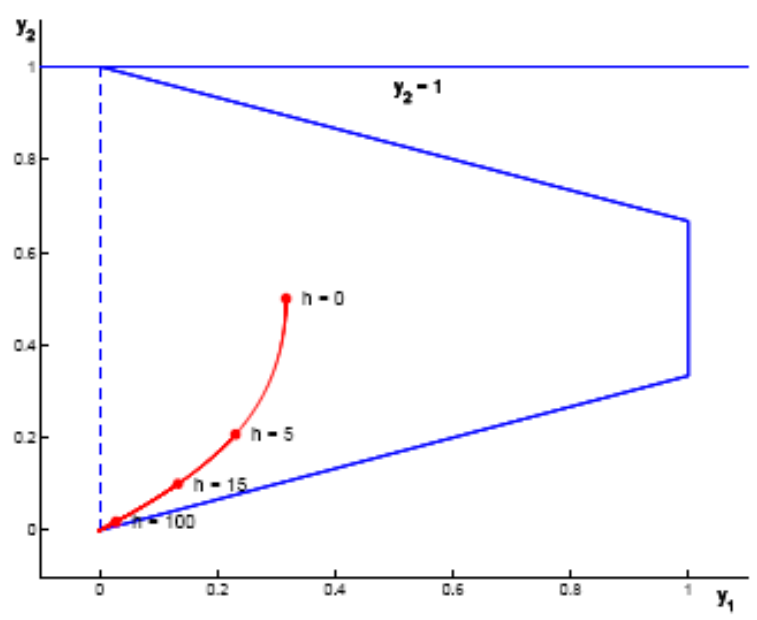

(d) $y_{2} \leq 1$

Gambar 1. Central path dari masalah redundan 2 dimensi Klee-Minty dimana kendala redundan sejajar dengan salah satu sumbu koordinat

Dengan menambahkan kendala redundan pada masalah Klee-Minty, dapat terjadi central path berada dekat dengan titik-titik pojok dari daerah fisibelnya. Hal ini akan berakibat buruk. Metode titik interior akan membutuhkan iterasi yang lebih banyak untuk menuju solusi optimal. Percobaan dilakukan dengan menambah kendala redundan $y_{1} \geq 0$ sebanyak 30 kali dan $y_{2} \geq 0$ sebanyak 150 kali.

Gambar 3 memperlihatkan central path dari masalah 2 dimensi Klee-Minty dengan kendala redundan tersebut. Central path berada dekat dengan titik-titik pojok dari daerah fisibelnya. Dengan menggunakan metode titik interior small-update path-following method, diperlihatkan pula (warna hitam) sebuah jalur yang ditempuh dalam mencari solusi optimal.

\subsection{Contoh kasus buruk lain}

Telah didiskusikan bahwa versi redundan dari masalah Klee-Minty dapat menyebabkan central path dipaksa berada cukup dekat dengan titik-titik ujung daerah fisibel,yang mengakibatkan unjuk kerja 
metode titik interior menjadi buruk. Gilbert, Gonzaga dan Karas memberikan contoh buruk central path pada masalah optimisasi konveks [5].

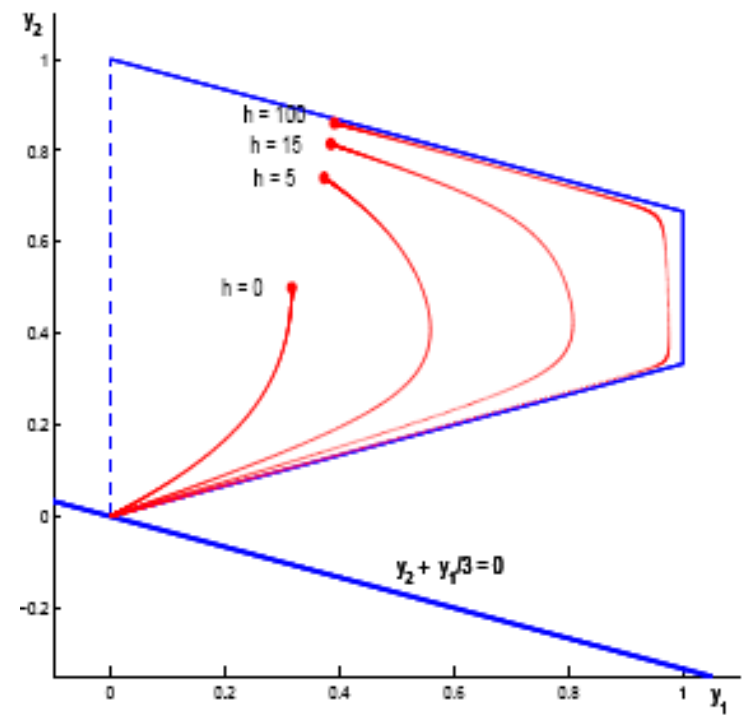

(a) $y_{2}+y_{1} / 3 \geq 0$

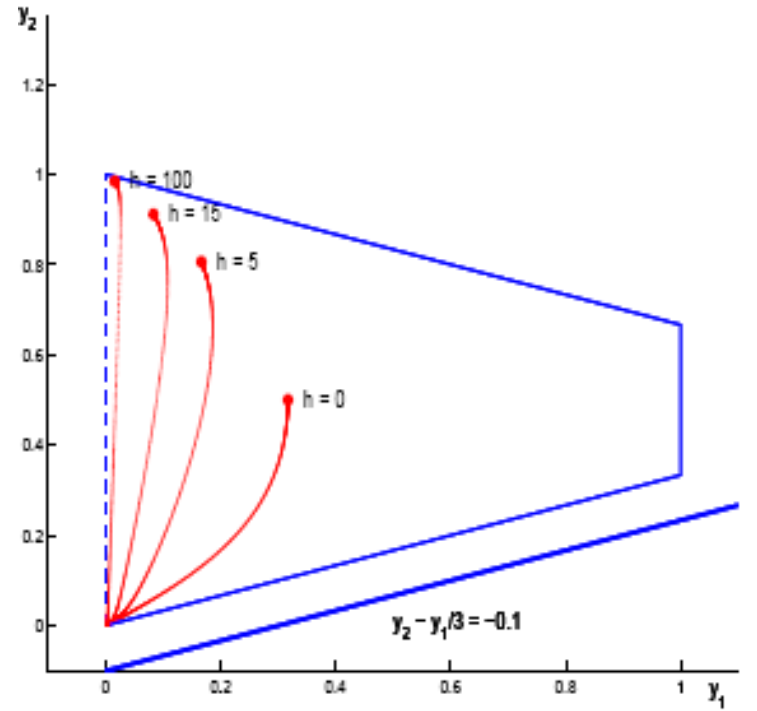

(c) $y_{2}-y_{1} / 3 \geq-0.1$

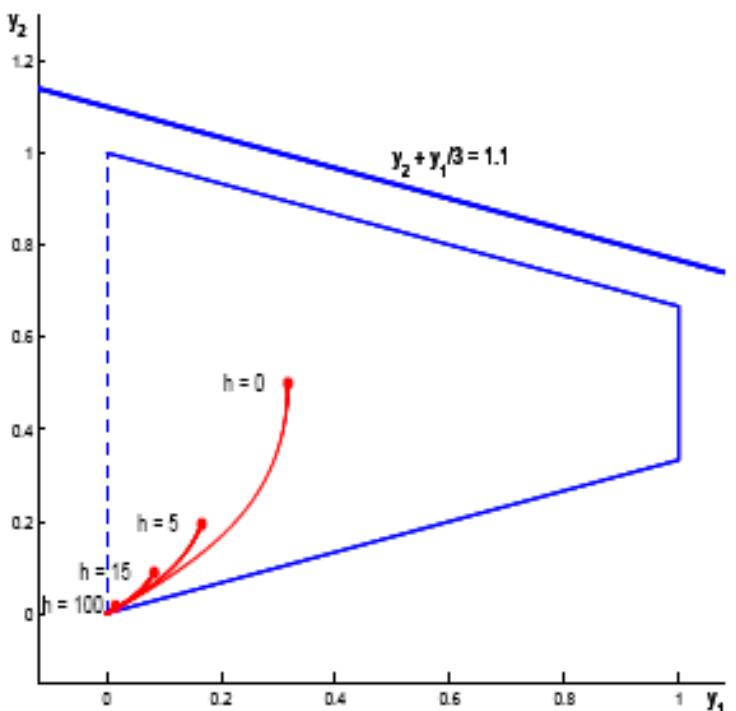

(b) $y_{2}+y_{1} / 3 \leq 1.1$

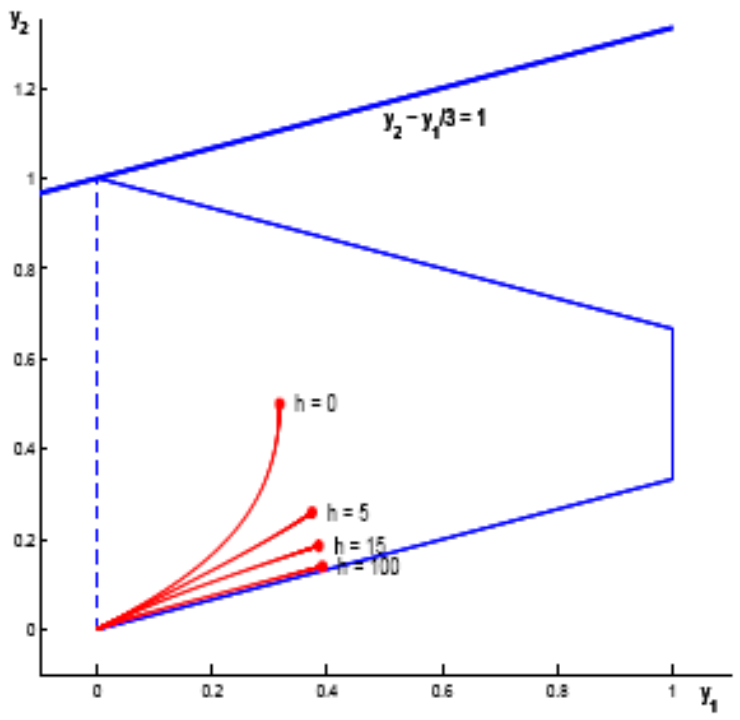

(d) $y_{2}-y_{1} / 3 \leq 1$

Gambar 2. Centrall path dari masalah redundan 2 dimensi Klee-Minty dimana kendala redundan sejajar dengan salah satu kendala

Berikut ini diperlihatkan suatu contoh dimana central path memiliki pola zigzag. Pola zigzag ini juga mengakibatkan metode titik interior lebih lama dalam memperoleh solusi optimal. Contoh berikut adalah varian dari contoh yang diberikan oleh Deza, Terlaky and Zinchenko [4]. 


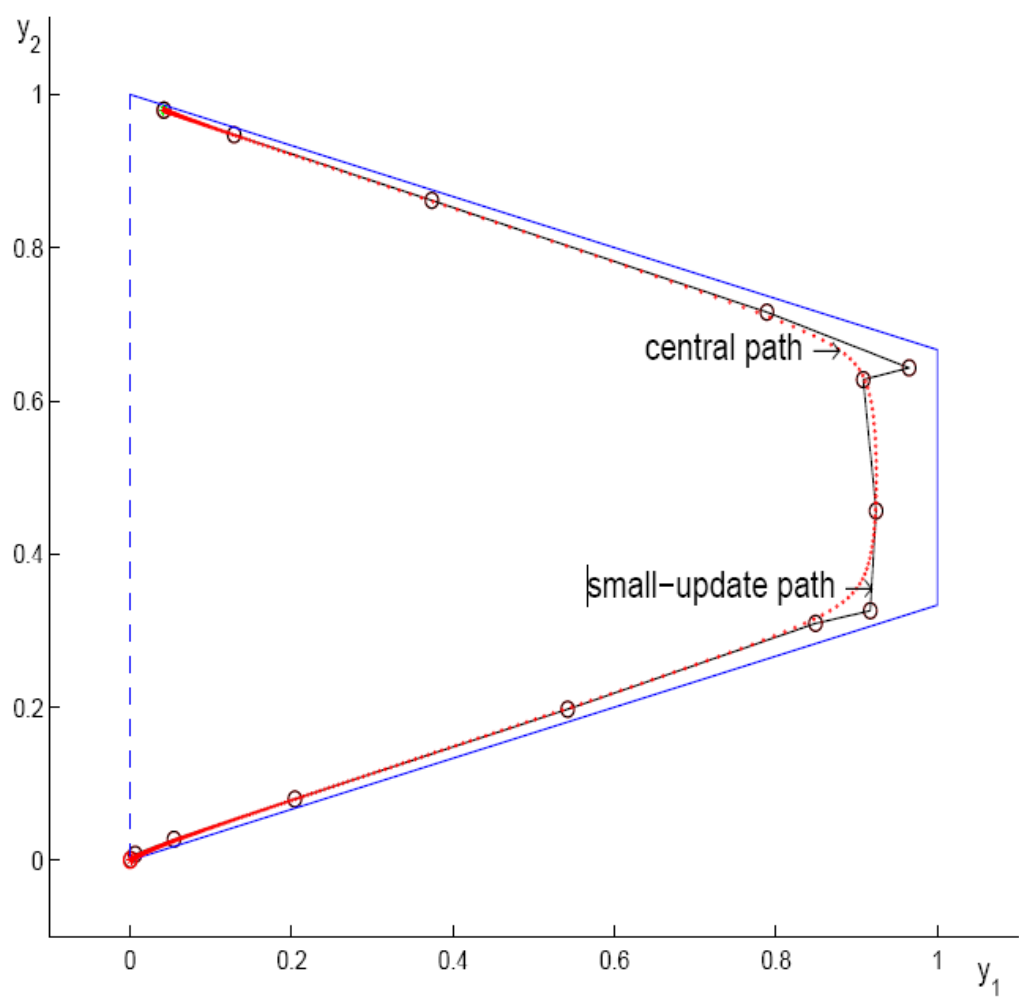

Gambar 3. Sebuah jalur metode titik interior masalah redundan 2 dimensi Klee-Minty dan central path-nya

Masalah OL dengan central path memiliki pola zigzag:

$$
\begin{aligned}
& \min y_{2} \\
& \text { kendala } 2 y_{2} \leq 1 \\
& \quad-2 y_{1}-y_{2} \leq 1 \\
& 5 y_{1}-y_{2} \leq 5 \\
& (-1)^{i+1} 11 y_{1}-10^{i+1} y_{2} \leq 5 \text {, untuk } i=1, \ldots, m-3 \text {, }
\end{aligned}
$$

dimana $m$ adalah jumlah pertidaksamaan. Solusi optimal masalah tersebut untuk $m \geq 5$ adalah:

$$
\left(y_{1}^{*}, y_{2}^{*}\right)=\left((-1)^{m-1} \frac{45}{121}, \frac{-1}{10^{m-3} 11}\right) .
$$

Ketika parameter $m$ bertambah, $y_{1}^{*}$ berubah-ubah antara 45/121 dan $-45 / 121$, sementara $y_{2}^{*}$ bertambah dengan lambat menuju nol. Hal ini mengakibatkan masalah tersebut memiliki central path dengan pola zigzag. Gambar 4 menunjukkan central path dari (14) untuk $m=$ 9 dan $m=22$. Terdapat $m-3$ belokan pada central path sebelum menuju solusi optimal, dan "lebar" belokan berkurang jika $\mu$ menurun menuju nol.

\section{Simpulan}

Metode titik interior dengan panduan central path dalam menuju solusi optimal memiliki unjuk kerja yang buruk pada kasus-kasus central path berada dekat dengan semua titik sudut pada daerah fisibelnya. Kasus ini dapat terjadi dengan adanya kendala redundan. Pola zigzag pada central path juga mengakibatkan metode titik interior berunjuk kerja buruk. Namun demikian kasus-kasus terburuk tersebut tetap dalam waktu polinomial. 


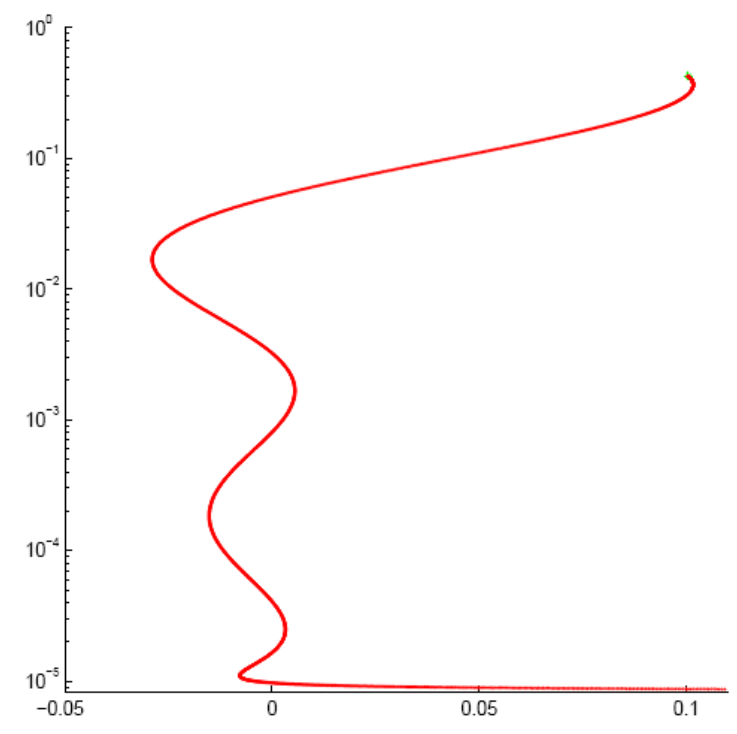

(a) $m=9$

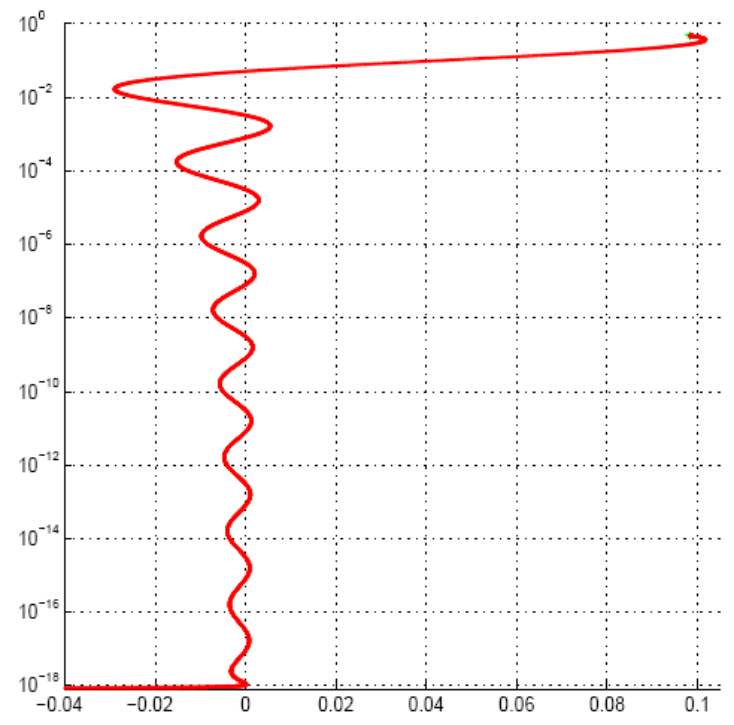

(b) $m=22$

Gambar 4. Pola zigzag central path masalah (14)

\section{Daftar Pustaka}

1. Dantzig, G. B., 1963., Linear Programming and Extensions.Princeton N.J.: Princeton University Press.

2. Deza, A., Nematollahi, E., Peyghami, R., and Terlaky, T., 2006, The central path visits all the vertices of the Klee-Minty cube, OptimizationMethods \& Software, 21(5), pages 851-865.

3. Deza, A., Nematollahi, E., and Terlaky, T., 2008, How good are interior point methods? Klee-Minty cubes tighten iteration-complexity bounds, Mathematical Programming 113(1, Ser. A), pages1-14.

4. Deza, A., Terlaky, T., and Zinchenko, Z., 2009,Central path curvature and iteration-complexity for redundant Klee-Minty cubes,Vol. 17, in Advances in applied mathematics and global optimization, page 223-256. New York: Springer.

5. Gilbert, J.C., Gonzaga, C.C., and Karas, E., 2005, Examples of ill-behaved central paths in convex optimization, Mathematical Programming 103, pages 63-94.

6. Karmarkar, N., 1984, A new polynomial-time algorithm for linear programming,Combinatorica(Springer-Verlag New York, Inc.) 4, no. 4, pages 373-395.

7. Khachiyan, L.G., 1980, Polynomial Algorithms in Linear Programming, Zhurnal Vychisditel'noi Matematiki $i$ Matematicheskoi Fiziki (Translated into English in USSR Computational Mathematics and Mathematical Physics 20, pages 53-72) 20, pages 51-68.

8. Klee, V., and Minty, G. J., How good is the simplex algorithm?, 1972,Inequalities, III (Proc. Third Sympos., Univ.California, Los Angeles, Calif., 1969; dedicated to the memory of Theodore S. Motzkin, pages 159-175), New York: Academic Press.

9. Nematollahi, E., and Terlaky, T., 2008, A simpler and tighter redundant Klee-Minty construction, Optimization Letters, 2(3), pages 403-414. 
10. Roos, C., and Vial, J.-Ph., 1992, A polynomial method of approximate centers for the linear programming problem, Mathematical Programming 54, pages 295-306.

11. Roos, C., Terlaky, T., and Vial, J.-Ph., 2006, Interior Point Methods for Linear Optimization.(Second edition of Theory and Algorithms for Linear Optimization, Wiley, Chichester, 1997). New York: Springer. 
B.P. Silalahi/ JMI Volume 10 No 1, April 2014, hal 9-17 